\title{
Task Trade and the Wage Effects of Import Competition
}

by

\author{
Abigail Cooke \\ University at Buffalo, SUNY
}

Thomas Kemeny

University of Southampton

\author{
David L. Rigby \\ University of California, Los Angeles
}

\begin{abstract}
CES 16-03
January, 2016

The research program of the Center for Economic Studies (CES) produces a wide range of economic analyses to improve the statistical programs of the U.S. Census Bureau. Many of these analyses take the form of CES research papers. The papers have not undergone the review accorded Census Bureau publications and no endorsement should be inferred. Any opinions and conclusions expressed herein are those of the author(s) and do not necessarily represent the views of the U.S. Census Bureau. All results have been reviewed to ensure that no confidential information is disclosed. Republication in whole or part must be cleared with the authors.

To obtain information about the series, see www.census.gov/ces or contact Fariha Kamal, Editor, Discussion Papers, U.S. Census Bureau, Center for Economic Studies 2K132B, 4600 Silver Hill Road, Washington, DC 20233, CES.Papers.List@census.gov. To subscribe to the series, please click here.
\end{abstract}




\begin{abstract}
Do job characteristics modulate the relationship between import competition and the wages of workers who perform those jobs? This paper tests the claim that workers in occupations featuring highly routine tasks will be more vulnerable to low-wage country import competition. Using data from the US Census Bureau, we construct a pooled cross-section (1990, 2000, and 2007) of more than 1.6 million individuals linked to the establishment in which they work. Occupational measures of vulnerability to trade competition - routineness, analytic complexity, and interpersonal interaction on the job - are constructed using O*NET data. The linked employer-employee data allow us to model the effect of low-wage import competition on the wages of workers with different occupational characteristics. Our results show that low-wage country import competition is associated with lower wages for US workers holding jobs that are highly routine and less complex. For workers holding nonroutine and highly complex jobs, increased import competition is associated with higher wages. Finally, workers in occupations with the highest and lowest levels of interpersonal interaction see higher wages, while workers with medium-low levels of interpersonal interaction suffer lower wages with increased low-wage import competition. These findings demonstrate the importance of accounting for occupational characteristics to more fully understand the relationship between trade and wages, and suggest ways in which task trade vulnerable occupations can disadvantage workers even when their jobs remain onshore.
\end{abstract}

Keyword: Task trade; import competition; wages; globalization; occupational characteristics; trade

\footnotetext{
* This research uses confidential data from the U.S. Census Bureau. Any opinions and conclusions expressed herein are those of the authors and do not represent the views of the U.S. Census Bureau. All results have been reviewed to ensure that no confidential information has been disclosed. Kemeny and Rigby acknowledge support for this project from the National Science Foundation under grant number BCS-0961735. Help by Arnie Reznek and Frank Limehouse at the U.S. Census Bureau on disclosure avoidance review is gratefully acknowledged.
} 


\section{1: Introduction}

Over the past half century, dramatic improvements in transportation technologies have significantly reduced the cost of moving goods (e.g., Levinson, 2006). Advances in communication technologies have simultaneously reduced the cost of information exchange. These changes have fostered great expansion in trade in services, and have enabled firms to better develop and control value chains distributed across the globe (Bonacich \& Wilson, 2008; Coe \& Yeung, 2015; Gereffi \& Korzeniewicz, 1994; Kleibert, 2015). The rise in the complexity and length of global production networks, related-party trade, and foreign direct investment flows indicate that growing numbers of businesses are exploiting newfound capacities to fragment production across developed and developing economies alike. Unlike traditional spatial divisions of labor based on finished goods such as those Ricardo described, or on monopolistic competition between varieties of goods as analyzed by Krugman (1979), the contemporary reworking of the production and trade landscape involves a much finer-grained division of production possibilities that Baldwin (2006), Blinder (2006) and Grossman and Rossi-Hansberg (2006) tie not to industries but to production tasks.

Tasks represent all the incremental steps of the production process necessary to design, test, construct, assemble, sell, and deliver intermediate goods and, eventually, final products and services. More specifically, Grossman and Rossi-Hansberg define tasks as "the finest possible addition to the value added of a good or service done by a particular factor of production” (2012, p. 595), with the production of intermediate goods comprised of "bundles" of tasks. The proliferation of task trade has relied on the ability to integrate and control distributed production networks, involving the efficient and cost-effective coordination of the movement of goods, services, and information across the globe. Task trade is remapping patterns of global trade and 
specialization. But it may also demand that we reconsider the links between trade and welfare. For instance, trade in tasks may involve shifts in trade distributional impacts. Specifically, education is becoming a less reliable indicator of whether that job is vulnerable to trade (e.g., Baldwin, 2006; Blinder, 2006; Blinder \& Krueger, 2013). This article responds to the need for more nuanced ways of capturing how trade influences worker well being. It builds on prior work that considers workers to be distinctive because of the kinds of tasks they perform. This work argues that relatively routine tasks, meaning those that can be readily codified, are increasingly vulnerable to being offshored (Baldwin 2006; Blinder 2006; Leamer and Storper 2001), or replaced by computers, robots and other technology (e.g. Autor, Levy, and Murnane 2003). In contrast, tasks that involve complex judgment-based decisions, and those requiring interpersonal interaction, are more costly to offshore and automate.

This paper explores whether the job characteristics of US workers influence how import competition from low-wage countries shapes their wages. We expect that workers will be more vulnerable to low-wage country import competition if the tasks they perform are (a) highly routine, (b) require little analytic complexity, and (c) involve scant interpersonal interaction. To test these hypotheses, we build standard measures of low-wage import competition using annual US Trade data, and relate these to a host of individual and establishment characteristics, derived from the US Census Bureau. We estimate pooled cross-sectional models predicting a worker's annual wages for 1.6 million workers across the years1990, 2000 and 2007. A worker’s occupation is the basis for their task profile, which we construct using information from the US Department of Labor's O*NET database. Overall, this dataset allows us to model the effect of low-wage import competition on the wages of workers with different occupational characteristics, net of the effects of education, demographics, and establishment characteristics. In relation to 
recent work in the same area, we add value in a few ways. Unlike Ebenstein et al (2014), we look beyond MNC offshoring to include arms-length sourcing captured in import records. Unlike Baumgarten et al. (2013), the present paper includes establishment characteristics whose omission may bias the attempt to link outcomes to trade. And we complement work by Hummels et al. (2014) by offering results from a different country context: the US, rather than Denmark. To preview the findings, we show that task intensity mediates the effect of low-wage import competition on workers’ wages. Import competition from low-wage countries is associated with lower wages for workers with highly routine manual jobs and workers with jobs that have low analytic complexity. At the same time, workers in jobs with low routine manual tasks and high analytic complexity earn higher wages when there is greater low-wage import competition. Together, these effects on high- and low- task intensity workers have a polarizing influence on wages along a task-intensity continuum, rewarding workers at one end of the spectrum and penalizing workers at the other end. The trade and wage relationship mediated by interpersonal task intensity is less straightforward. Workers in occupations with high levels of interpersonal interaction have higher wages when there is greater import competition from lowwage countries. Interestingly, the same is true for workers with the lowest levels of interpersonal interaction in their jobs, though the size of the coefficient is much smaller. Only workers with medium-low levels of interpersonal interaction in their occupations suffer lower wages with increased low-wage import competition. Interaction effects show that the mediating relationship of task intensity is non-linear. These results demonstrate the importance of accounting for occupational characteristics to more fully understand the relationship between trade and wages and suggest ways in which task-trade-vulnerable occupations disadvantage workers even when their jobs remain onshore. 
The remainder of this article proceeds as follows. Section 2 provides a review of the literature on task trade and labor market effects. Section 3 outlines an empirical model to capture the importance of task characteristics in describing the relationship between trade and wages. Data sources, variable construction, and a series of empirical concerns are discussed. Section 4 presents the results from estimating a series of related statistical models. Section 5 concludes, summarizing the key findings.

\section{2: Task trade and labor market effects: A brief review of the literature}

Trade in intermediate goods has been recognized for some time (for example, Baldwin, 2006; Coe, Hess, Yeung, Dicken, \& Henderson, 2004; Dixit \& Grossman, 1982; Robert C. Feenstra \& Gordon H. Hanson, 1996; Gereffi \& Korzeniewicz, 1994; Grossman \& RossiHansberg, 2006, 2008; Helpman, 1984). However, the concept of trade in tasks rather than intermediates is not merely old wine in new bottles. Task trade demands substantial retheorization, especially in regards to trade's welfare impacts. Attention to tasks suggests that who will be affected by trade is more "unpredictable" than previous theories of trade would lead us to believe (e.g., Baldwin, 2006; Baldwin \& Robert-Nicoud, 2006). It is no longer low-skill workers or production workers who are vulnerable to international competition, and the jobs that are vulnerable can shift quickly as technological changes enable better and cheaper coordination across long distances. Moreover, the fine grained level of competition in task trade makes clear that the effects will be differentially located within firms and within groups of workers previously thought to share the same fate (Baldwin \& Robert-Nicoud, 2006). Thus, recent work suggests that production tasks in high-wage economies requiring substantial formal education or 
skill development are no longer “safe” from offshoring (Baldwin, 2006; Blinder, 2006), complicating both modeling efforts as well as policy responses. This prompts reconsideration of what characteristics might be more definitive in understanding the contours of trade impacts, some of which rest on what makes something tradable, and thus possible to offshore, or not.

\section{Characteristics of tasks that make them vulnerable to offshoring}

An evolving body of work identifies key characteristics of different tasks that influence the ease with which they might be produced in different locations. Many important issues are being developed in the literature (e.g., see Blinder \& Krueger, 2013), including: the precise nature of these characteristics; which are most important; how to measure them; and the number of jobs in high-wage economies that could be affected.

Building from extant theoretical and empirical contributions we focus herewith on three key task characteristics: manual routineness, analytical complexity, and interpersonal interaction.

Autor, Levy, and Murnane define routine tasks as those requiring "a limited and welldefined set of cognitive and manual activities, those that can be accomplished by following explicit rules” (2003, p. 1280). This task profile is in decline in high-wage economies like the US, UK and Germany (e.g., Autor, Levy, \& Murnane, 2003; Goos \& Manning, 2007; Spitz-Oener, 2006), and research has suggested it responds negatively to investments in technology, as computers and other forms can efficiently replicate such tasks. At the same time it captures intuitions about shifting patterns of trade, such as the relocation of most garment and footwear production - as an example of routine labor - from higher-wage to low-wage countries. This 
intuition has been formalized in economic models, such as Grossman \& Rossi-Hansberg (2006), and Baldwin and Robert-Nicoud (2014). ${ }^{1}$

Leamer and Storper (2001) also argue that routineness allows some tasks to be performed far away from the headquarters or management. They argue that routineness is not necessarily a characteristic of individual tasks but rather of the coordination between them. For example, can the tasks be coordinated with codifiable information or do they require more tacit information necessitating trust and understanding between the parties? Newly fractured production processes may technically be performed in any number of places, but coordinating all the parts can be costly enough to keep the task fragments located together. Later, when the new process and the coordination of the set of tasks is routinized and codified, those tasks are more likely to move abroad to cheaper locations. The newness of fragmentation in a particular production process (Leamer and Storper, 2001) is not possible to observe directly in any of the data available to us. However certain aspects of the coordination factor are possible to capture in two further characteristics: analytical complexity (also called nonroutiness in the literature) and interpersonal interaction.

Autor et al. define 'nonroutiness' in opposition to their characterization of routine tasks as involving "problem-solving and complex communication activities” (2003, p. 1280). However, we prefer Oldenski’s (2011) related concept of ‘complexity’ as involving creativity, problemsolving, and decision-making, because it indicates that there are aspects of this concept that do not follow perfectly along a continuum from routine to nonroutine, but involve additional characteristics. Conceptually helpful, it also corresponds to the possibilities of constructing measures for routineness and complexity that are negatively correlated, but not perfectly so.

\footnotetext{
${ }^{1}$ The model Grossman and Rossi-Hansberg (2006) develop is agnostic as to what actually makes a task vulnerable to offshoring or not (e.g., p. 13), but their discussion of tasks tends towards the routine/nonroutine division. (e.g., p. 10-11).
} 
Oldenski offers the likelihood of problems arising that management must solve as determining which activities are likely to be actually offshored. She thus ties in some of the insights from Leamer and Storper that the coordination of the tasks is as important as the tasks themselves in determining what parts of the production process are not only technically footloose but likely to leave.

The interpersonal interaction characteristic speaks partly to the Leamer and Storper (2001) tacit coordination factor, but also draws on the personal/impersonal division Blinder (2006) develops with regard to the services sector. Blinder offers this distinction as the key factor in whether a task can be offshored, with impersonal services being those "that can be delivered electronically over long distances with little or no degradation in quality” (p. 114). This concept is also applicable to business-service oriented occupations within the manufacturing sector, such as management jobs. This concept (whether a task is “interactive” or not) is also used by Becker et al. (2013) and Baumgarten et al (2013).

\section{Theoretical models}

Beyond the models commonly used to understand impacts of trade on workers and firms (e.g., Bernard, Jensen, \& Schott, 2006; Ethier, 2005; Robert C. Feenstra \& Gordon H. Hanson, 1996; Robert C. Feenstra \& Gordon H. Hanson, 1996; Feenstra \& Hanson, 2001), there are a number of explicit models of task trade. ${ }^{2}$ The present research draws most heavily upon Grossman and Rossi-Hansberg (2008), who develop a model of task trade in which what is

\footnotetext{
${ }^{2}$ Other models of task trade effects on labor markets include: an extension of the Grossman and Rossi-Hansberg model that investigates the job destruction and creation effects of offshoring by relaxing full-employment conditions (Kohler \& Wrona, 2011) and finds that jobs are destroyed as offshoring occurs, but the productivity effect can compensate for the job destruction effect in the long term under certain conditions; an update of the basic Heckscher-Ohlin framework that conceptualizes offshoring as 'shadow migration' of endowments, finding that Stolper-Samuelson predictions hold for the home country, implying that in countries like the U.S., inequality in the wages paid to skilled- and unskilled labor should rise with increased offshoring; and offshoring within a monopolistic competition framework (e.g., (Robert-Nicoud, 2008); Grossman and Rossi-Hansberg 2012).
} 
traded, or offshored, is determined by weighing the costs of monitoring and controlling workers in another country against the potential savings from lower labor costs in that other country. The costs of coordinating workers from a distance are assumed to be lower for more routine tasks than for nonroutine tasks, and routine tasks are more likely to be performed by low-wage workers and nonroutine tasks by high-wage workers (e.g., Autor et al., 2003). Reductions in trade costs, particularly communications costs, lead to increased offshoring of trade-vulnerable tasks.

In this model, the increase in offshoring reduces costs and affects wages in the highwage (onshore) country in three ways: through terms of trade effects (reducing the price of the imported goods since they are likely made by workers with lower wages); labor supply effects (with demand decreasing for workers with the task trade vulnerable characteristics), and; productivity effects (where the onshore workers refocus on higher-productivity tasks).

The aggregate effect of these three wage effects is not clear from the model itself. The first two effects suggest that (real) wages for workers in the home country will fall, but the third effect suggests that average wages could rise. It is likely that these three effects of offshoring impact workers differentially. Those workers least able to respond to the new challenges of higher productivity tasks could still benefit from rising wages tied to average productivity increases, but are less likely to directly benefit from these shifts in general. These distributional effects are confirmed in Rojas-Romagoas (2010) who runs numerical simulations of the Grossman and Rossi-Hansberg model and finds that with nearly all combinations of endowments, robust to a wide a range of parameters, the model leads to increased inequality in the onshore, high-wage country. 


\section{Closely related empirical work}

Much of the empirical work on task trade has so far has focused on the shifts in demand for workers engaged in jobs with different task-intensities. Though Autor, Levy and Murnane (2003) focused on computerization rather than trade, they offer an important early approach to understanding demand for task-intensity. They found that increased computerization decreased relative demand for jobs that involved routine, codifiable tasks and raised the relative demand for non-manual, nonroutine tasks.

More closely related to the trade literature, Oldenski (2011) focuses on the decisions by MNCs to move tasks either offshore to foreign affiliates or to outsource them domestically. She posits that not everything that can technically be offshored is actually moved abroad and applies the routine-nonroutine dichotomy to the offshoring decision. She finds that U.S. MNCs were more likely to offshore routine tasks to foreign affiliates and more likely to keep complex and nonroutine tasks in the U.S.

Kemeny and Rigby (2012) develop a somewhat similar approach to Oldenski, but they ask a broader question of what effect trade from low-wage countries has on the demand for occupations with different task characteristics. Their work captures the important effects of task trade accomplished through arms-length transactions, rather than solely what happens within the enterprise boundaries of MNCs. They find that import competition from low-wage countries increases sector-specific demand for nonroutine tasks, both in the form of interpersonal interaction and nonroutine analytical tasks. However, demand for nonroutine manual tasks is negatively related to import competition. Similar work has been done using data from outside the United States. Research has shown evidence of 1) shifts in Germany in the nonroutine-routine worker ratio as related-party trade with developing countries increases (Becker et al., 2013), 2) 
skill-upgrading in the face of trade in Belgium (Mion \& Zhu, 2013) and Argentina (Bustos, 2011), and 3) production job losses in France from imports (Biscourp \& Kramarz, 2007).

Together these papers advance our understanding of the shifts in demand for tasks with various offshoring-vulnerable characteristics. Less studied is how these shifts in demand translate into worker impacts. A few important exceptions exist: Ebenstein et al. (2013) examine the effect of offshoring from U.S. MNCs on the wages of U.S. workers, focusing not on industry-level exposure to globalization, but rather on occupation-level exposure. They find that offshoring to low-wage countries lowers the wages of U.S. workers with routine jobs. Offshoring to high-wage countries has the opposite effect on these workers, raising the wages of those performing routine tasks. Overall, the net effect of offshoring on the wages of workers with routine jobs is negative, largely through the reallocation of workers from high-wage industries to lower-wage industries. They also find that for workers with the least routine jobs, increased offshoring is associated with higher wages. Ottaviano et al. (2013) relate shifts in MNC offshoring activities to the reallocation of employment, considering domestic effects on both natives and immigrants. They find evidence of a link between offshoring and greater demand for natives performing communication-intensive tasks. Baumgarten et al. (2013) examine the offshoring impacts on individuals' wages in Germany, paying particular attention to how the task characteristics of a worker's occupation mitigate negative impacts of offshoring, even net of their education level. They find substantial negative wage effects from offshoring, particularly when they allow for cross-industry offshoring effects, essentially assuming that workers can find work in their chosen occupation in a number of industries. They also find that high intensity of nonroutineness or interactivity in occupations mitigates the negative wage effects of offshoring. Hummels et al. (2014) also address the question of the effects of offshoring on individual wages, 
including specifically looking at the role of tasks in moderating these affects. Using Danish matched employer-employee data, they find that routine occupations (within skill groups) are associated with wage losses from offshoring.

This article builds on previous research to make several new contributions. It observes the wage effects of the impacts of trade on task demand identified by Kemeny and Rigby (2012). It complements the work of Ebenstein et al. (2014) by examining the wage effects not only associated with a measure of routineness, but also two other key task characteristics of interpersonal interaction and complexity. It also complements Baumgarten et al. (2013) and Hummels et al. (2014) by offering a somewhat similar analysis using the case of the U.S. Finally, it includes establishment-level characteristics as control variables on the individual wages outcomes, something not possible without matched employer-employee data and thus not included in much of the previous research (with Hummels et al. 2014 as an important exception).

\section{3: Empirical strategy}

We seek to measure the extent to which the relationship between a worker's wage and import competition from low-wage countries depends on the worker's task characteristics. The analysis rests on two assumptions. First, that commodity imports from low-wage countries embody routine labor functions that substitute for U.S. workers engaged in jobs with the same task characteristics and thus lowering their wages. Second, that imports from low-wage countries complement work done by U.S. workers with tasks that are high in interpersonal interaction and that involve high complexity in creativity, decision-making, and problem-solving. We expect this 
complementary relationship to raise the wages of U.S. workers in occupations with high taskintensity in interpersonal interaction and complexity.

To examine these relationships, we use a basic wage model that relates individual reported annual wages to low-wage import competition, task intensity, and several control variables:

$W=f(P E R S O N, E S T A B, M I G R A T I O N$, SBTC, TASK INTENSITY, LWICOMP $)$

where $W$ represents the annual wages of a worker, PERSON represents the worker's demographic characteristics, including education level, ESTAB represents the workplace characteristics where the individual is employed, MIGRATION represents the regional loweducation migration context, SBTC represents skill-biased technological change, TASK INTENSITY is the level of a particular task necessary in the worker's occupation, and LWICOMP represents import competition from low-wage countries.

Matched employer-employee data and task intensity construction

The analytical sample utilized to examine how task characteristics mediate the relationship between trade and wages are a set of matched employers and employees. These data are constructed from confidential versions of the U.S. Census Bureau’s Decennial Census, American Community Survey (ACS), and Census of Manufactures (CMF). Manufacturing workers in the Decennial and ACS are matched probabilistically to establishments in the CMF based on industry and census tracts. Where there is not a unique match to an establishment because there is more than one plant with the same industry in a Census tract and year, the 
characteristics of the establishments within the industry and Census tract are averaged into synthetic plants. For a more detailed explanation of the construction of these matched data, see (Cooke 2014).

The measure of low-wage country import competition (LWICOMP) is the ratio of lowwage imports within industry $i$ in year $t$ to the value of output in industry $i$ and year $t$ that is available for domestic consumption, a commonly used measure of import competition (see (Bernard et al., 2006):

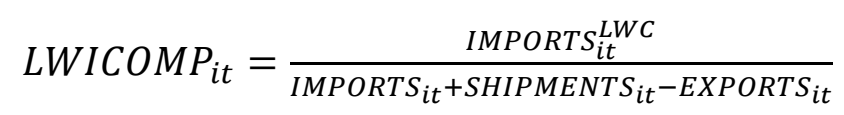

where IMPORTS $S_{i t}^{L W C}$ is the value of imports to the U.S. in industry $i$ at time $t$ originating in lowwage countries and IMPORTS $i t$ is the value of imports from all countries; SHIPMENTS $i t$ is the total U.S. domestic production (shipments) and EXPORTS $i t$ represents U.S. exports. Imports and exports, by industry and year, are derived from the individual level transactions compiled by the Foreign Trade Division of the U.S. Census Bureau. Shipments are from the CMF, aggregated from the establishment level to industry-year measures. ${ }^{3}$ Low-wage countries are defined by the World Bank country classification. We use countries classified in the low-income group for 1992 to determine the group of low-wage countries used throughout our period of analysis. These

\footnotetext{
${ }^{3}$ To construct the imports and exports, we use a crosswalk developed by Pierce and Schott (2012) to translate the product level information (10-digit Harmonized System (HS) codes) into the manufacturing industries that produce those products. The Pierce and Schott crosswalk translates HS product codes to North American Industry Classification System (NAICS) industry codes. To enable matching with the Decennial and ACS data, we further aggregate the NAICS industries (over 450 codes in the manufacturing sector) into Census Bureau industry codes (roughly 72 codes in manufacturing), which are the industry codes assigned to people with work experience in the demographic Censuses and Surveys collected by the U.S. Census Bureau. CMF shipments data are similarly constructed and aggregated.
} 
countries had Gross National Income (GNI) per capita less than or equal to US\$545 in $1992 .{ }^{4}$ That year, 1992, is the earliest year of trade data available in our data and also captures more consistent definitions for many countries included in the study (e.g., former Soviet countries). This set of 51 countries (notably including China) remains consistent in our LWICOMP calculations, even though some of the 51 countries have moved out of the World Bank low income class by 2007. See Appendix A for the list of low-wage countries.

Key independent variables are the occupational characteristics or job attributes of each worker. O*NET (Occupational Information Network) is a publicly available dataset from the U.S. Department of Labor that gives descriptors of different characteristics of occupations, based on surveys of workers in each occupation. ${ }^{5}$ Within O*NET, 'work activities' correspond most closely to the conceptions of tasks developed in the theoretical literature and follow previous empirical work using O*NET (Oldenski 2012). ${ }^{6}$ To generate measures of task-intensity for each occupation, we use principal components analysis to reduce several work activities down to individual measures of particular task characteristics. The input variables and the constructed primary components are summarized in Table 1. Following Oldenski (2012), we create a single measure of routine manual labor using the primary component among performing general physical activities, handling and moving objects, and controlling machines and processes (“routine manual”). We depart from Oldenski’s nonroutineness measure that incorporates both creativity and communication, opting instead for two separate measures. The first captures

\footnotetext{
${ }^{4}$ See the World Bank's Atlas methodology documentation for more details on how this was calculated: http://data.worldbank.org/indicator/NY.GNP.PCAP.CD.

${ }^{5}$ O*NET Resource Center: http://www.onetcenter.org/; O*NET Revision 14

${ }^{6}$ In an interesting alternative approach, Becker et al. (2013) (and following them, Baumgarten et al. 2013) base their measures of the intensity of the tasks "non-routine" and "interactive" using the tools commonly deployed in each occupation.
} 
analytical and decision making tasks (“complex analytic”) built from a combination of analyzing, decision making and problem solving, creative thinking, and objectives and strategies development. The second is a measure of interpersonal interaction intensity ("complex interpersonal”), based on communications, relationship management, conflict resolution, and consulting and advising others.

[Table 1 about here]

Table 2 shows the task intensities for several example occupations to help ground these concepts in some concrete examples. In Panel A, below each task intensity measure (routine manual, complex analytic, and complex interpersonal) are the component dimensions. The component dimensions are measured on a scale from 0 to 1 . The task intensity measures are transformed so that the entire range is always a positive number. Note that the scales for each task intensity measure are not comparable. Panel B shows the range of variation in the values in terms of standard deviations, with the industrial production manager as the reference category (Column 1). The other occupations involve far more routine manual tasks - ranging from just over a half a standard deviation (sewing machine operators - Column 5) to over one and a half standard deviations (cutting, punching, pressing machine operators - Column 4). Industrial production managers have higher levels of complex analytical and interpersonal task measures than the other occupations. Here, the levels of these tasks are two to three standard deviations lower among these occupations compared to the production manager. This table shows not only the substantial variation in these measures across particular occupations, but also reveals reassuringly intuitive comparisons across the occupations. 
[Table 2 about here]

Once constructed, we linked the three occupation-specific task intensity scores to individual workers based on each individual's occupation as reported in the Decennial and ACS. The resulting dataset is a pooled cross-section (1990, 2000, and 2007) that includes over 1.6 million individuals. For each individual worker we measure annual wages and basic demographic characteristics, including educational attainment. Establishment characteristics where each individual works are also included. Finally, a measure of industry-year import competition from low-wage countries is attached to each individual.

For the entire analytical sample, Table 3 shows the means, standard deviations, and the correlations among the task intensity measures, wages, computer share of investment, education categories, and low-wage import competition. The measure of routine manual tasks is negatively correlated with that of both complex analytic and interpersonal tasks. Routine manual is also negatively correlated with wages, whereas complex analytic and interpersonal are positively correlated with wages.

[Table 3 about here]

\section{Estimation}

The aim of the analysis is to explore how different job or task characteristics mediate the relationship between low-wage country import competition and the wages of U.S. manufacturing workers. We estimate a series of regression models to do so. The dependent variable in these 
models is annual wages and observations correspond to individual workers over the years examined. Workers are placed into quartiles according to where their occupation lies along an index of task intensity for a given task type - routine manual, complex analytic and complex interpersonal. We then focus on estimating our relationship of interest for workers in the highest and lowest quartile for each, in order to most clearly highlight differentiated effects. Equation (3) outlines the base model specification.

$$
\begin{gathered}
W_{j t o}=a+\boldsymbol{\beta}_{u}^{\prime} \boldsymbol{P}_{u j g t}+\boldsymbol{\beta}_{v}^{\prime} \boldsymbol{E}_{v k t}+\beta_{1} M_{j i t s}+\beta_{2} S B T C_{k t}+\beta_{3} L_{W I C O M P}+ \\
\delta_{t}+\delta_{i}+\delta_{s}+\varepsilon_{j i t}
\end{gathered}
$$

where $W_{j t o}$ is the wage of worker $j$ in time $t$ in group o of a particular task; $\boldsymbol{P}_{j g t}$ is a $u$-element vector of worker characteristics for worker $j$ in group o of a particular task intensity, including age, sex, nativity, and race-ethnicity, and education level; $\boldsymbol{E}_{k t}$ denotes a $v$-element vector of features of establishment $k$, establishment size, capital-labor ratio, and value of exports; $M_{j i t s}$ is a measure of the prevalence of low-education immigrant workers in the industry and state of the worker; $S B T C_{k t}$ is an establishment-specific measure of the share of investments made by that establishment in computers, capturing skill-biased technological change; $L W I C O M P_{i t}$ is the measure of import competition from low-wage countries, specific to each industry and year. This specification also includes three fixed effects terms: $\delta_{t}$ is a year dummy that accounts for business cycle dynamics and other time-specific shocks; $\delta_{i}$ is an industry fixed effect that captures sector-specific wage shocks unrelated to trade; $\delta_{s}$ absorbs state-specific shocks. Finally, $\varepsilon$ is an error term that is assumed to satisfy classical regression assumptions. 
We estimate these equations as pooled cross-sections using ordinary least squares. However, those results could be biased if LWICOMP is correlated with sector-specific demand or productivity changes in the U.S. not captured elsewhere in the model. To account for this potential endogeneity bias, we instrument for LWICOMP using a measure of year- and industryspecific imports into the EU-15 European nations from the same low-wage countries used in the LWICOMP construction in equation (3). This measure is constructed from the United Nations COMTRADE data. The logic of this instrument assumes that the European countries face similar exposure to low-wage import competition when imports reflect factors inherent in low-wage countries, or in the dynamic of trade between low-wage and high-wage countries, but that demand side factors in domestic wages should be relatively uncorrelated across different countries. This instrument, used in specifications employing two stage least squares, should help give estimates of the exogenous effect of low-wage import competition on wages in U.S. manufacturing.

\section{4: Results}

We estimate equation (3) for groups of workers that fall into quartiles of each task intensity measure. Thus, we estimate wages using OLS and two-stage least-squares for workers in occupations with low, medium-low, medium-high, and high task intensity measures. To highlight the contrasts, the middle categories are not shown (except for low-medium complex interpersonal); they are available upon request. Every model includes state, industry, and year fixed effects. This process is repeated for each of the three task intensity measures. The first results reported are for workers grouped by the level of routine manual tasks in their occupations. 
Routine manual tasks, low-wage import competition, and wages, by quartiles

Table 4 reports estimates of the relationship between low-wage import competition and wages for workers grouped by the level of routine manual tasks in their occupations. The first column reports the results for low-routine manual workers, meaning workers with occupations that score low on moving and handling objects, general physical activities, and controlling machines. For these workers, increases in import competition raises wages, fitting with expectations. The establishment characteristics produce results that are somewhat more mixed. Though not statistically significant, it is surprising that the computer share of investment and the value of export shipments are both negatively related to wages for this group of workers. The size of the establishment and the capital/labor ratio of the plant are positively and significantly related to wages, as expected. The demographic characteristics are generally in line with expectations: being male, older, white and non-Hispanic, and having higher levels of formal education are all associated with higher wages. Interestingly, for this group, being born in the U.S. is negatively and significantly associated with wages, suggesting that native born workers in this group are earning less than their foreign born counterparts. Finally, the contextual variables operate as expected: Working in a state and industry with a high percentage of low-education foreign born workers is associated with lower wages; working in a metro area is positively associated with higher wages.

[Table 4 about here] 
For workers with high routine manual tasks in their occupations (Column 2), low-wage import competition is negatively and significantly associated with wages. For these workers, the demographic, establishment, and contextual characteristics operate as expected. Note that the computer share of investments is negative and significant, perhaps indicating capital-labor substitution for workers with more routine manual jobs.

Columns 3 and 4 in Table 4 presents results estimated using two-stage least-squares fixed effects estimators, using EU imports as an instrument for LWICOMP. In all models the first stage diagnostics reported at the bottom of the table indicate the suitability of the instrument. The Kleibergen-Paap K-P rk LM Chi-squared/p-value statistics indicate that the instrumented model passes this underidentification test. The Kleibergen-Paap (K-P) F-statistic reports on the instrument relevance, here with a value well above the critical Stock-Yogo value. We conclude that the instrument is relevant and not weak. Unfortunately with only one instrument, we cannot report statistics relevant to overidentification and thus discuss the exogeneity of the instrument (e.g., Hanson’s J).

The results in these columns are broadly similar to the results from the OLS estimation (Columns 1 and 2). Differences of note include coefficients for low-wage import competition that are roughly double (Column 3) the OLS coefficients in the first category (low routine manual). Also of note is that the coefficient for import competition for the most routine jobs (Column 4) is negative, but not statistically significant. This result is not predicted, however, it is not entirely surprising given the much smaller LWICOMP coefficient in the OLS models for this group (Column 2).

It is difficult to assess which set of regression coefficients provides the best estimates of the influence of import competition between the two sets of models in Table 4. The OLS results 
might be compromised with endogeneity issues. However, use of instrumental variables also generates bias in estimated coefficients. In addition, the relatively large standard errors in the 2SLS models - they are roughly double the size of the LWICOMP standard errors in the OLS models - also suggests loss of precision in estimation. Regardless, the two sets of results are broadly consistent with each other and indicate that for workers with the least routine manual task in their occupations, imports from low-wage countries are complementary to their work and increase their wages. The opposite is true for workers with more routine manual tasks in their jobs. For these workers, import competition is generally associated with lower wages.

Complex analytic tasks, low-wage import competition, and wages, by quartiles

Turning to the second type of task intensity, Table 5 presents results from estimations for workers grouped by the complex analytic task intensity of their occupations. Recall that this task characteristic includes elements of creative thinking, analysis, problem-solving, decisionmaking, and developing objectives and strategies. The order of the columns is the same as the previous table, with lowest intensity in Column 1 (and 3) and highest intensity in Column 2 (and 4). However, because complex analytic tasks are negatively correlated with routine manual tasks, the intuition of which workers will be negatively affected by trade competition is reversed in these tables.

[Table 5 about here]

In Table 5, Column 1, which reports the OLS estimates for the group of workers with the lowest-complex analytic jobs, low-wage import competition is negatively and significantly 
associated with wages. As the complex analytic tasks required in occupations increases beyond this lowest quartile, the relationship is reversed. In Column 2, with results for workers with the greatest intensity of complex analytic tasks in their jobs, the relationship between low-wage import competition and wages is positive and significant. So for these workers, increased lowwage import competition is associated with higher wages.

The other covariates operate in much the way we might expect, with two notable features. The first is that for the group with the most complex analytic jobs, nativity is negatively and significantly associated with wages, meaning that U.S. born workers have lower wages than their foreign-born counterparts. For the other group of workers, in jobs that have low complex analytic task intensity, being born in the U.S. is associated with significantly higher wages. The second notable feature is the negative relationship between the computer share of investment and wages for both groups. However, note that the effect is larger for the low group and is small and not statistically significant for the highest group. This is consistent with the idea that computer investment substitutes for labor in less complex analytic tasks. However, if skill-biased technical change were operating strongly, we would also expect to see the wages (revealed productivity) of workers with the most complex jobs increase.

In the two-stage least-squares models shown in Table 5, Columns 3 and 4, the results are consistent with the OLS results. The first-stage test statistics lead us to conclude that the model is not underidentified and that the instrument is not weak. The notable difference between the two sets of results is that the coefficient on LWICOMP for the 2SLS models are roughly double what they are in the OLS results. The standard errors for LWICOMP in the 2SLS models are also roughly double what they are in the OLS models. 
Complex interpersonal tasks, low-wage import competition, and wages, by quartiles

Finally, turning to the third type of task intensity: complex interpersonal tasks. Table 6 is structured similarly to the previous tables.

[Table 6 about here]

Table 6 Column 1 reports results for workers with low complex interpersonal task intensity in their occupation. Contrary to expectations, low-wage import competition has a positive and significant association with wages for this group. For these workers, the low levels of interpersonal interaction (communicating with people outside the organization, establishing and maintaining personal relationships, resolving conflicts, and providing consultations and advice) would seem to fit with the idea that imports from low-wage countries could be competitive rather than complementary for these workers, but this is not what the results show. For the other groups of workers, however, the results support the idea that interpersonal interaction intensive jobs should be less vulnerable to offshoring, and therefore also more likely to benefit from low-wage imports. In Column 2, the medium-low intensity group displays a negative and significant relationship between LWICOMP and wages. In Column 3, the group with highest intensity of complex interpersonal tasks in their occupations, low-wage import competition is positively and significantly related to wages. The other covariates operate as expected. Even though the results for the lowest group (Column 1) defy expectation on the sign of the coefficient, the coefficient for that group compared to the highest group (Column 3) is much smaller. In this sense, this is consistent with theoretical expectations. 
The instrumented 2SLS results (Table 6, Column 3 and 4) have the same pattern as the OLS results, and again the first-stage test statistics lead us to conclude that the model is not underidentified and the instrument is not weak. As in previous tables, the 2SLS results have much larger coefficients on low-wage import competition than the OLS results.

Though consistent with expectations in terms of the magnitude of the coefficients for the lowest and highest groups, the unexpected sign on the LWICOMP coefficient for the workers with the least interpersonal interaction is not easy to explain. It is possible that the variables used to construct the measure of interpersonal interaction are missing a crucial aspect of vulnerability to offshoring; they give a good sense of the necessity of face-to-face communication, but they do not capture the necessity of physical presence that might not require communication. Janitors might be a good example. They do not necessarily need to talk much to do their jobs effectively and so would score low on the interpersonal interaction measure, but they also cannot email or ship their work in from another country. So it is possible that this constructed measure of interpersonal interaction is not capturing everything intended. Alternatively, it is possible the findings are valid as is. They are consistent with some of the literature looking at the polarization in the workforce in countries like the U.S and U.K., where employment and wages are gaining at the very top and very bottom of the wage spectrum, but 'hollowing out' in the middle (e.g., Goos \& Manning, 2007).

Interacting LWC import competition and task characteristics

In addition, we estimated equation on all the workers pooled together and included a variable interacting LWICOMP and each task intensity measure separately (see Table 7). The results reveal that the effect of LWICOMP is greater as task intensity increases. Thus, net of the 
effect of LWICOMP and routineness by themselves, LWICOMP has a larger negative effect on wages as routineness increases. Complexity and interpersonal interaction show the same pattern, but with the sign reversed to reflect their positive association with wages. The interacted term shows that as the complexity, or level of interpersonal interaction, increases, the positive effect on wages from LWICOMP also increases. The coefficients on these variables - LWICOMP, the task intensity measure, and the interaction between the two - are all statistically significant at the $1 \%$ level.

\section{5: Conclusion}

An important feature of the changes in international trade over the past few decades is increasing fragmentation of production processes across countries linked by trade transactions, referred to as task trade. One of the key implications of this fine-grained fragmentation is that it changes what can conceivably be separated out of the production process and produced elsewhere. This specialization of production in different countries linked by trade is now occurring at the level of tasks and no longer at the level of sectors. Education and production/ nonproduction status among workers tells us less about how workers are affected by trade and are no longer the only way to conceptualize and measure vulnerability to trade competition. It is helpful to think about other ways the effects of trade might be 'visible.'

To address this, we examine the effects of trade on workers based on the intensity of key task characteristics in occupations. This paper asks how different task intensities mediate the relationship between low-wage import competition and wages of U.S. manufacturing workers. It finds that low-wage import competition is associated with lower wages for workers with highly 
routine manual jobs and workers with low complex analytic intensity jobs. It also finds that workers in jobs with low routine manual tasks and high complex analytic tasks earn higher wages when there is greater import competition. Looking at interpersonal interaction, this paper provides a slightly less straightforward finding. Workers with the lowest and highest levels of complex interpersonal tasks in their occupations receive higher wages in the face of higher import competition, but workers with medium-low intensity of this characteristic have lower wages with greater import competition. Interactions show that the magnitude of the effect is not linear, but grows as the task intensity grows.

In general, these results suggest that workers who perform tasks that are theoretically more vulnerable to offshoring and task trade face negative wage effects associated with lowwage import competition. The map of global trade continues to shift as the imperatives of capitalism respond to changes in technology. As it does, workers face new challenges and opportunities. At least in the US, in response to increasing competition from low-wage country imports, these challenges and opportunities appear to have a polarizing effect on workers' wages, based partly on the characteristics of their occupations. 


\section{References:}

Autor, D. H., Levy, F., \& Murnane, R. J. (2003). The Skill Content of Recent Technological Change: An empirical exploration. Quarterly Journal of Economics, 118(4), 1279-1333. doi:doi:10.1162/003355303322552801, http://www.mitpressjournals.org/doi/abs/10.1162 1003355303322552801

Baldwin, R. (2006). Globalisation: the great unbundling(s). Finland: Prime Minister's Office, Economic Council of Finland.

Baldwin, R., \& Robert-Nicoud, F. (2006). Offshoring and globalisation: What is new about the new paradigm? Graduate Institute of International Studies, Geneva.

Baldwin, R., \& Robert-Nicoud, F. (2014). Trade-in-goods and trade-in-tasks: An integrating framework. Journal of International Economics, 92(1), 51-62.

Baumgarten, D., Geishecker, I., \& Görg, H. (2013). Offshoring, tasks, and the skill-wage pattern. European Economic Review, 61(0), 132-152. doi:http://dx.doi.org/10.1016/j.euroecorev.2013.03.007

Becker, S. O., Ekholm, K., \& Muendler, M.-A. (2013). Offshoring and the onshore composition of tasks and skills. Journal of International Economics, 90(1), 91-106.

Bernard, A. B., Jensen, J. B., \& Schott, P. K. (2006). Survival of the best fit: Exposure to lowwage countries and the (uneven) growth of U.S. manufacturing plants. Journal of International Economics, 68(1), 219-237. Retrieved from http://www.sciencedirect.com/science/article/B6V6D-4GX0CS41/2/b319c626b075190245389727cd5f4aef

Biscourp, P., \& Kramarz, F. (2007). Employment, skill structure and international trade: Firmlevel evidence for France. Journal of International Economics, 72(1), 22-51. doi:http://dx.doi.org/10.1016/j.jinteco.2006.07.005

Blinder, A. S. (2006). Offshoring: The Next Industrial Revolution? Foreign Affairs, 85(2), 113128.

Blinder, A. S., \& Krueger, A. B. (2013). Alternative Measures of Offshorability: A Survey Approach. Journal of Labor Economics, 31(2), S97-S128. doi:10.1086/669061

Bonacich, E., \& Wilson, J. B. (2008). Getting the goods: Ports, labor, and the logistics revolution: Cornell University Press.

Bustos, P. (2011). The Impact of Trade Liberalization on Skill Upgrading. Evidence from Argentina. Economics Working Papers.

Coe, N. M., Hess, M., Yeung, H. W.-c., Dicken, P., \& Henderson, J. (2004). 'Globalizing' regional development: a global production networks perspective. Transactions of the Institute of British Geographers, 29(4), 468-484. doi:10.1111/j.0020-2754.2004.00142.x

Coe, N. M., \& Yeung, H. W.-c. (2015). Global production networks: Theorizing economic development in an interconnected world: OUP Oxford.

Dixit, A. K., \& Grossman, G. M. (1982). Trade and Protection with Multistage Production. The Review of Economic Studies, 49(4), 583-594. doi:10.2307/2297288

Ebenstein, A., Harrison, A., McMillan, M., \& Phillips, S. (2013). Estimating the Impact of Trade and Offshoring on American Workers Using the Current Population Surveys. Review of Economics and Statistics. doi:10.1162/REST_a_00400

Ethier, W. J. (2005). Globalization, globalisation: Trade, technology, and wages. International Review of Economics \& Finance, 14(3), 237-258. doi:http://dx.doi.org/10.1016/j.iref.2004.12.001 
Feenstra, R. C., \& Hanson, G. H. (1996). Foreign Investment, Outsourcing, and Relative Wages. In R. C. Feenstra, G. M. Grossman, \& D. A. Irwin (Eds.), The Political Economy of Trade Policy: Papers in Honor of Jagadish Bhagwati (pp. 89-127). Cambridge, MA: MIT Press.

Feenstra, R. C., \& Hanson, G. H. (1996). Globalization, Outsourcing, and Wage Inequality. The American Economic Review, 86(2), 240-245. Retrieved from http://www.jstor.org/stable/2118130

Feenstra, R. C., \& Hanson, G. H. (2001). Global Production Sharing and Rising Inequality: A Survey of Trade and Wages: SSRN.

Gereffi, G., \& Korzeniewicz, M. (1994). Commodity Chains and Global Capitalism: ABC-CLIO.

Goos, M., \& Manning, A. (2007). Lousy and Lovely Jobs: The Rising Polarization of Work in Britain. Review of Economics and Statistics, 89(1), 118-133. doi:doi:10.1162/rest.89.1.118 \%U http://www.mitpressjournals.org/doi/abs/10.1162/rest. $\underline{89.1 .118}$

Grossman, G. M., \& Rossi-Hansberg, E. (2006). The rise of offshoring: it's not wine for cloth anymore.

Grossman, G. M., \& Rossi-Hansberg, E. (2008). Trading Tasks: A Simple Theory of Offshoring. American Economic Review, 98(5), 1978-1997. doi:doi: 10.1257/aer.98.5.1978

Grossman, G. M., \& Rossi-Hansberg, E. (2012). Task Trade Between Similar Countries. Econometrica, 80(2), 593-629. doi:10.3982/ecta8700

Helpman, E. (1984). A simple theory of international trade with multinational corporations. The Journal of Political Economy, 451-471.

Kemeny, T., \& Rigby, D. (2012). Trading away what kind of jobs? Globalization, trade and tasks in the US economy. Review of World Economics, 148(1), 1-16. doi:10.1007/s10290-0110099-5

Kleibert, J. M. (2015). Islands of globalisation: Offshore Services and the Changing Spatial Divisions of Labour. Environment and Planning A, 47(4), 884-902. doi:10.1068/a140119p

Kohler, W., \& Wrona, J. (2011). Offshoring tasks, yet creating jobs? University of Tübingen working papers in economics and finance, 12.

Krugman, P. R. (1979). Increasing returns, monopolistic competition, and international trade. Journal of International Economics, 9(4), 469-479.

Leamer, E. E., \& Storper, M. (2001). The Economic geography of the Internet Age. Journal of International Business Studies, 32(4), 641-665.

Levinson, M. (2006). The Box: How the Shipping Container Made the World Smaller and the World Economy Bigger Princeton University Press.

Mion, G., \& Zhu, L. (2013). Import competition from and offshoring to China: A curse or blessing for firms? Journal of International Economics, 89(1), 202-215. doi:http://dx.doi.org/10.1016/j.jinteco.2012.06.004

Oldenski, L. (2011). The Task Composition of Offshoring by U.S. Multinationals. Mimeo.

Robert-Nicoud, F. (2008). Offshoring of routine tasks and (de)industrialisation: Threat or opportunityâ€”And for whom? Journal of Urban Economics, 63(2), 517-535. doi:http://dx.doi.org/10.1016/j.jue.2007.03.002

Rojas-Romagosa, H. (2010). Wage inequality in trade-in-tasks models: CPB Netherlands Bureau for Economic Policy Analysis. 
Spitz-Oener, A. (2006). Technical Change, Job Tasks, and Rising Education Demands: Looking outside the wage structure. Journal of Labor Economics, 24, 235-270. 
Figures and Tables:

Table 1: Variable Construction - Principal Component Analysis

Variables

\begin{tabular}{lc}
\hline \multirow{3}{*}{ Routine Manual } & Component Variables from O*NET \\
\cline { 2 - 3 } Complex Analytic & $\begin{array}{c}\text { Performing General Physical Activities } \\
\text { Handling and Moving Objects } \\
\text { Controlling Machines and Processes }\end{array}$ \\
\cline { 2 - 2 } Analyzing Data or Information \\
Making Decisions and Solving Problems \\
Thinking Creatively \\
\cline { 2 - 2 } Complex Interpersonal \\
Developing Objectives and Strategies \\
Communicating with Persons Outside \\
Organization \\
Establishing and Maintaining Interpersonal \\
Relationships \\
Resolving Conflicts and Negotiating with Others \\
Provide Consultation and Advice to Others
\end{tabular}




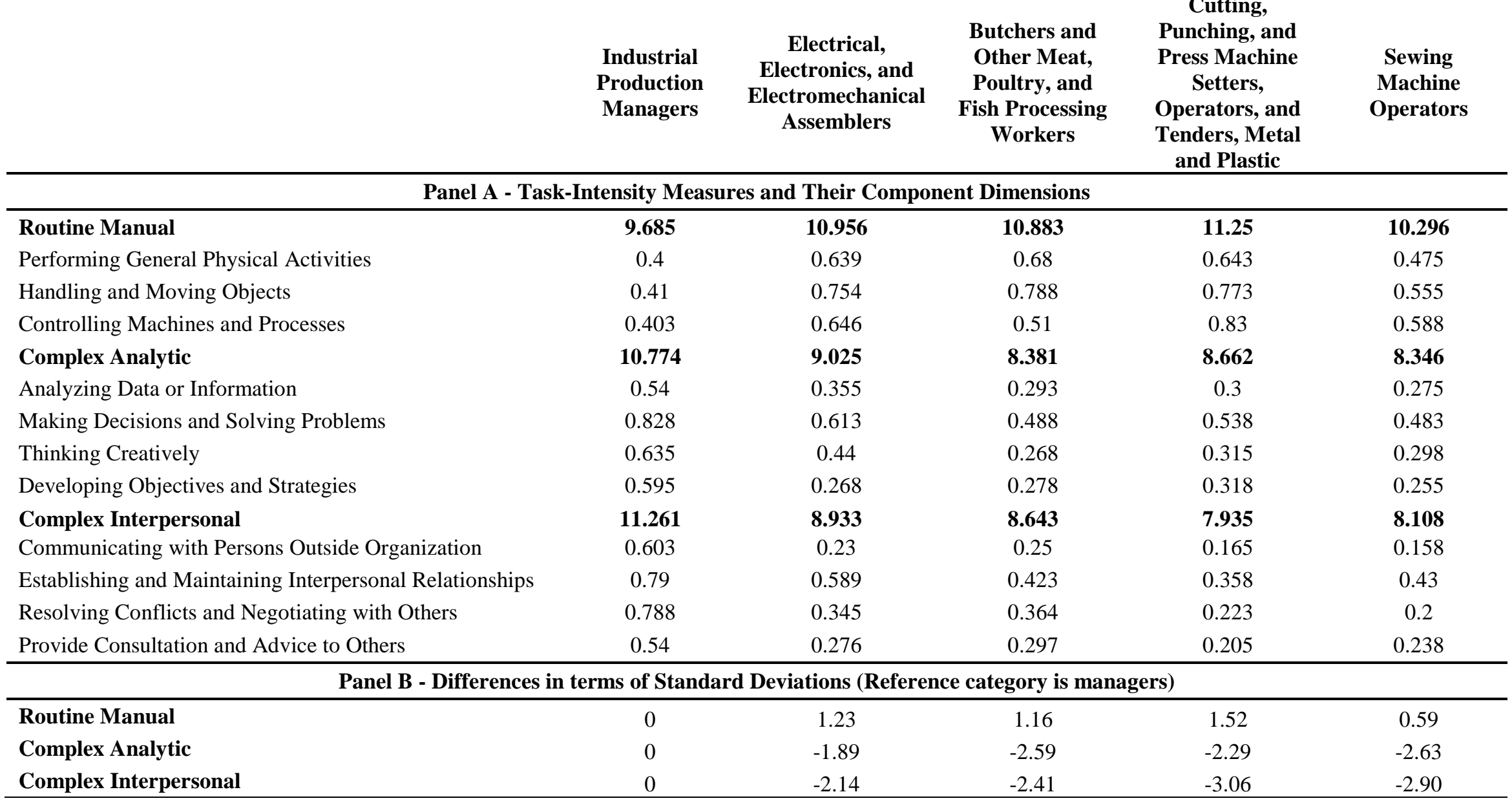


Table 3: Means, Standard Deviations, and Correlations for Occupational Characteristic Sample

\begin{tabular}{|c|c|c|c|c|c|c|c|c|c|}
\hline & Mean & S.D. & Wage & $\begin{array}{l}\text { Computer } \\
\text { Share of } \\
\text { Investments }\end{array}$ & $\begin{array}{l}\text { Education } \\
\text { category }\end{array}$ & LWICOMP & $\begin{array}{l}\text { Complex } \\
\text { Analytical }\end{array}$ & $\begin{array}{l}\text { Routine } \\
\text { Manual }\end{array}$ & $\begin{array}{l}\text { Complex } \\
\text { Inter- } \\
\text { personal }\end{array}$ \\
\hline Wage & 40797 & 39703 & 1 & & & & & & \\
\hline Computer Share of Investments & 0.0941 & 0.322 & 0.020 & 1 & & & & & \\
\hline Education category & 1.664 & 1.125 & 0.351 & 0.035 & 1 & & & & \\
\hline LWICOMP & 0.036 & 0.067 & 0.029 & 0.043 & -0.001 & 1 & & & \\
\hline Complex Analytic & 9.931 & 0.924 & 0.345 & 0.028 & 0.441 & -0.032 & 1 & & \\
\hline Routine Manual & 10.07 & 1.033 & -0.282 & -0.043 & -0.497 & -0.067 & -0.532 & 1 & \\
\hline Complex Interpersonal & 9.757 & 1.087 & 0.330 & 0.024 & 0.425 & 0.001 & 0.757 & -0.709 & 1 \\
\hline
\end{tabular}


Table 4: Routine Manual Tasks and LDC Import Competition - Relationship to Wages: OLS and 2SLS Models

\begin{tabular}{|c|c|c|c|c|}
\hline & $\begin{array}{l}\text { (1) } \\
\text { Low Routine } \\
\text { Manual } \\
\text { OLS }\end{array}$ & $\begin{array}{l}\text { (2) } \\
\text { High Routine } \\
\text { Manual } \\
\text { OLS }\end{array}$ & $\begin{array}{l}\text { (3) } \\
\text { Low Routine } \\
\text { Manual } \\
\text { 2SLS } \\
\end{array}$ & $\begin{array}{l}\text { (4) } \\
\text { High Routine } \\
\text { Manual } \\
\text { 2SLS }\end{array}$ \\
\hline Sex, $1=$ male & $\begin{array}{c}23154.21 \\
(206.92)^{* * *} \\
-2066.17\end{array}$ & $\begin{array}{c}7716.48 \\
(114.55) * * * \\
2487.88\end{array}$ & $\begin{array}{c}23132.86 \\
(207.14)^{* * *} \\
-1956.20\end{array}$ & $\begin{array}{c}7702.23 \\
(114.86)^{* * *} \\
2489.79\end{array}$ \\
\hline Nativity, $1=$ US born & $(478.70) * * *$ & $(181.37)^{* * *}$ & $(479.73) * * *$ & $(181.34) * * *$ \\
\hline $\begin{array}{l}\text { Ethnicity-Race Dummy (White \& } \\
\text { Not Hispanic=1) }\end{array}$ & $\begin{array}{c}10664.19 \\
(369.07)^{* * *}\end{array}$ & $\begin{array}{c}3274.87 \\
(157.85) * * *\end{array}$ & $\begin{array}{c}10726.90 \\
(369.45) * * *\end{array}$ & $\begin{array}{c}3279.31 \\
(157.73) * * *\end{array}$ \\
\hline Age & $\begin{array}{c}900.76 \\
(10.90)^{* * *} \\
5583.12\end{array}$ & $\begin{array}{c}310.08 \\
(3.73)^{* * *} \\
3067.08\end{array}$ & $\begin{array}{c}900.93 \\
(10.91)^{* * *} \\
5506.98\end{array}$ & $\begin{array}{c}309.96 \\
(3.73) * * * \\
3058.78\end{array}$ \\
\hline Work in a Metro Area (1=yes) & $(310.53)^{* * *}$ & $(93.86)^{* * *}$ & $(311.07)^{* * *}$ & $(93.75)^{* * *}$ \\
\hline $\begin{array}{l}\text { \% foreign born with < GED in } \\
\text { labor force, state-industry }\end{array}$ & $\begin{array}{c}-234.91 \\
(27.37)^{* * *} \\
0.0009\end{array}$ & $\begin{array}{c}-98.49 \\
(12.12)^{* * *} \\
0.0027\end{array}$ & $\begin{array}{c}-211.52 \\
(27.50)^{* * *} \\
0.0009\end{array}$ & $\begin{array}{c}-97.45 \\
(12.09)^{* * *} \\
0.0027\end{array}$ \\
\hline Total Value of Shipments & $\begin{array}{c}(0.0002)^{* * *} \\
0.77\end{array}$ & $\begin{array}{c}(0.0002)^{* * *} \\
4.47\end{array}$ & $\begin{array}{c}(0.0002)^{* * *} \\
0.80\end{array}$ & $\begin{array}{c}(0.0002)^{* * *} \\
4.49\end{array}$ \\
\hline Capital/Labor Ratio & $\begin{array}{l}(0.25)^{* * *} \\
-0.0002\end{array}$ & $\begin{array}{c}(0.42)^{* * *} \\
0.0002\end{array}$ & $\begin{array}{l}(0.25)^{* * *} \\
-0.0002\end{array}$ & $\begin{array}{c}(0.42)^{* * *} \\
0.0002\end{array}$ \\
\hline Value of Export Shipments & $\begin{array}{l}(0.0005) \\
-401.32\end{array}$ & $\begin{array}{l}(0.0006) \\
-1360.69\end{array}$ & $\begin{array}{l}(0.0005) \\
-414.40\end{array}$ & $\begin{array}{l}(0.0006) \\
-1394.97\end{array}$ \\
\hline Computer Share of Investments & $\begin{array}{l}(447.05) \\
12440.55\end{array}$ & $\begin{array}{c}(262.65) * * * \\
2914.36\end{array}$ & $\begin{array}{l}(447.93) \\
12448.60\end{array}$ & $\begin{array}{c}(264.45)^{* * *} \\
2913.86\end{array}$ \\
\hline Education Categories & $(122.69)^{* * *}$ & $(54.50)^{* * *}$ & $(122.83)^{* * *}$ & $(54.48)^{* * *}$ \\
\hline $\begin{array}{l}\text { Import Competition (Complex), } \\
\text { WB 'Low' in } 1992\end{array}$ & $\begin{array}{c}28818.64 \\
(3,119.38)^{* * *}\end{array}$ & $\begin{array}{c}-8859.59 \\
(1,639.24)^{* * *}\end{array}$ & $\begin{array}{c}67197.35 \\
(6,338.14)^{* * *}\end{array}$ & $\begin{array}{l}-3475.70 \\
(4269.15)\end{array}$ \\
\hline Observations (rounded to 1000s) & 403000 & 360000 & 403000 & 360000 \\
\hline R-squared & 0.23 & 0.26 & - & - \\
\hline $\mathrm{F}$ & 487.64 & 546.99 & 487.59 & 518.24 \\
\hline Prob $>$ F & 0 & 0 & 0 & 0 \\
\hline $\begin{array}{l}\text { Kleibergen-Paap rk LM statistic } \\
\text { (underidentification) } \\
\text { Chi-sq(1) P-val }\end{array}$ & & & $\begin{array}{c}1.10 \mathrm{E}+004 \\
0\end{array}$ & $\begin{array}{c}1390.401 \\
0\end{array}$ \\
\hline $\begin{array}{l}\text { Cragg-Donald Wald F statistic } \\
\text { (weak identification) } \\
\text { Kleibergen-Paap rk Wald F } \\
\text { statistic } \\
\text { Instrument }\end{array}$ & & & $\begin{array}{l}3.70 \mathrm{E}+004 \\
\text { EU Imports }\end{array}$ & $\begin{array}{c}3931.098 \\
\text { EU Imports }\end{array}$ \\
\hline
\end{tabular}

Robust standard errors in parentheses

* significant at 10\%; ** significant at 5\%; *** significant at $1 \%$

NB: Industry, State, and Year fixed effected included in all models 
Table 5: Complex Analytic Tasks and LDC Import Competition - Relationship to Wages:

OLS and 2SLS Models

\begin{tabular}{|c|c|c|c|c|}
\hline & $\begin{array}{c}\mathbf{( 1 )} \\
\text { Low Complex } \\
\text { Analytic } \\
\text { OLS } \\
\end{array}$ & $\begin{array}{c}\text { (2) } \\
\text { High Complex } \\
\text { Analytic } \\
\text { OLS }\end{array}$ & $\begin{array}{c}\text { (3) } \\
\text { Low Complex } \\
\text { Analytic } \\
\text { 2SLS } \\
\end{array}$ & $\begin{array}{c}\mathbf{( 4 )} \\
\text { High Complex } \\
\text { Analytic } \\
\text { 2SLS } \\
\end{array}$ \\
\hline Sex, 1=male & $\begin{array}{c}7763.71 \\
(86.05)^{* * *} \\
3151.31\end{array}$ & $\begin{array}{c}17505.75 \\
(202.19) * * * \\
-1536.08\end{array}$ & $\begin{array}{c}7769.43 \\
(86.06)^{* * *} \\
3126.81\end{array}$ & $\begin{array}{c}17451.04 \\
(202.86)^{* * *} \\
-1476.43\end{array}$ \\
\hline Nativity, 1=US born & $(168.17)^{* * *}$ & $(426.53) * * *$ & $(168.91)^{* * *}$ & $(427.26)^{* * *}$ \\
\hline $\begin{array}{l}\text { Ethnicity-Race Dummy (White \& } \\
\text { Not Hispanic=1) }\end{array}$ & $\begin{array}{c}2800.82 \\
(136.89)^{* * *} \\
269.82\end{array}$ & $\begin{array}{c}12503.96 \\
(338.99)^{* * *} \\
1066.09\end{array}$ & $\begin{array}{c}2785.91 \\
(136.64)^{* * *} \\
270.00\end{array}$ & $\begin{array}{c}12532.74 \\
(338.88) * * * \\
1065.78\end{array}$ \\
\hline Work in a Metro Area (1=yes) & $\begin{array}{c}(3.56)^{* * *} \\
2852.99 \\
(98.45) * * *\end{array}$ & $\begin{array}{c}(10.65)^{* * *} \\
5826.49 \\
(274.60) * * *\end{array}$ & $\begin{array}{c}(3.56)^{* * *} \\
2875.70 \\
(98.61) * * *\end{array}$ & $\begin{array}{c}(10.65)^{* * *} \\
5781.10 \\
(274.72)^{* * *}\end{array}$ \\
\hline $\begin{array}{l}\text { \% foreign born with <GED in } \\
\text { labor force, state-industry }\end{array}$ & $\begin{array}{c}-34.07 \\
(7.76)^{* * *} \\
0.0021\end{array}$ & $\begin{array}{c}-195.21 \\
(23.99)^{* * *} \\
0.0010\end{array}$ & $\begin{array}{c}-36.07 \\
(7.74)^{* * *} \\
0.0021\end{array}$ & $\begin{array}{c}-180.26 \\
(24.04)^{* * *} \\
0.0010\end{array}$ \\
\hline Total Value of Shipments & $\begin{array}{c}(0.0001)^{* * *} \\
0.95\end{array}$ & $\begin{array}{c}(0.0001)^{* * *} \\
0.97\end{array}$ & $\begin{array}{c}(0.0001)^{* * *} \\
0.93\end{array}$ & $\begin{array}{c}(0.0001)^{* * *} \\
0.99\end{array}$ \\
\hline Capital/Labor Ratio & $\begin{array}{c}(0.30)^{* * *} \\
0.0009\end{array}$ & $\begin{array}{c}(0.24)^{* * *} \\
0.0001\end{array}$ & $\begin{array}{c}(0.30)^{* * *} \\
0.0009\end{array}$ & $\begin{array}{c}(0.24)^{* * *} \\
0.0001\end{array}$ \\
\hline Value of Export Shipments & $\begin{array}{l}(0.0005)^{*} \\
-1177.54\end{array}$ & $\begin{array}{l}(0.0004) \\
-70.09\end{array}$ & $\begin{array}{l}(0.0005)^{*} \\
-1128.77\end{array}$ & $\begin{array}{l}(0.0004) \\
-74.42\end{array}$ \\
\hline Computer Share of Investments & $\begin{array}{c}(199.65)^{* * *} \\
3181.03\end{array}$ & $\begin{array}{c}(84.89) \\
13522.97\end{array}$ & $\begin{array}{c}(196.78) * * * \\
3182.96\end{array}$ & $\begin{array}{c}(84.99) \\
13511.51\end{array}$ \\
\hline Education Categories & $(53.28)^{* * *}$ & $(103.53)^{* * *}$ & $(53.35) * * *$ & $(103.58)^{* * *}$ \\
\hline $\begin{array}{l}\text { Import Competition (Complex), } \\
\text { WB 'Low' in } 1992\end{array}$ & $\begin{array}{c}-12715.78 \\
(1,258.13)^{* * *}\end{array}$ & $\begin{array}{c}23095.10 \\
(3,064.85)^{* * *} \\
\end{array}$ & $\begin{array}{c}-20428.76 \\
(1,920.76)^{* * *}\end{array}$ & $\begin{array}{c}46070.37 \\
(6,133.06)^{* * *}\end{array}$ \\
\hline Observations (rounded to 1000s) & 408000 & 474000 & 408000 & 474000 \\
\hline R-squared & 0.2 & 0.2 & - & - \\
\hline $\mathrm{F}$ & 457.1 & 411.45 & 450.1 & 411.72 \\
\hline Prob $>$ F & 0 & 0 & 0 & 0 \\
\hline $\begin{array}{l}\text { Kleibergen-Paap rk LM statistic } \\
\text { (underidentification) } \\
\text { Chi-sa(1) P-val }\end{array}$ & & & $\begin{array}{c}2795.646 \\
0\end{array}$ & 9347.055 \\
\hline $\begin{array}{l}\text { Cragg-Donald Wald F statistic } \\
\text { (weak identification) } \\
\text { Kleibergen-Paap rk Wald F } \\
\text { statistic } \\
\text { Instrument }\end{array}$ & & & $\begin{array}{l}1.50 \mathrm{E}+004 \\
\text { EU Imports }\end{array}$ & $\begin{array}{l}3.50 \mathrm{E}+004 \\
\text { EU Imports }\end{array}$ \\
\hline
\end{tabular}

Robust standard errors in parentheses

* significant at 10\%; ** significant at 5\%; *** significant at $1 \%$

NB: Industry, State, and Year fixed effected included in all models 
Table 6: Complex Interpersonal Tasks and LDC Import Competition - Relationship to Wages: OLS and 2SLS Models

\begin{tabular}{|c|c|c|c|c|c|}
\hline & $\begin{array}{c}\mathbf{( 1 )} \\
\text { Low } \\
\text { Complex } \\
\text { Interpersona } \\
1 \\
\text { OLS }\end{array}$ & $\begin{array}{c}(\mathbf{2}) \\
\text { Med-low } \\
\text { Complex } \\
\text { Interpersona } \\
\text { 1 } \\
\text { OLS }\end{array}$ & $\begin{array}{l}\text { High } \\
\text { Complex } \\
\text { Interpersonal } \\
\text { OLS }\end{array}$ & $\begin{array}{l}\text { Low } \\
\text { Complex } \\
\text { Interpersonal } \\
\text { 2SLS }\end{array}$ & $\begin{array}{c}\text { (5) } \\
\text { High } \\
\text { Complex } \\
\text { Interpersona } \\
\text { l } \\
\text { 2SLS }\end{array}$ \\
\hline Sex, $1=$ male & $\begin{array}{c}8869.93 \\
(102.70)^{* * *} \\
729.83\end{array}$ & $\begin{array}{c}8882.59 \\
(90.81)^{* * *} \\
2619.68\end{array}$ & $\begin{array}{c}22785.20 \\
(278.99)^{* * *} \\
-5162.38\end{array}$ & $\begin{array}{c}8771.12 \\
(102.79)^{* * *} \\
765.47\end{array}$ & $\begin{array}{c}22730.88 \\
(279.59)^{* * *} \\
-5093.23\end{array}$ \\
\hline Nativity, 1=US born & $(182.30)^{* * *}$ & $(163.74)^{* * *}$ & $(677.92)^{* * *}$ & $(182.48)^{* * *}$ & $(678.78)^{* * *}$ \\
\hline $\begin{array}{l}\text { Ethnicity-Race Dummy (White \& } \\
\text { Not Hispanic=1) }\end{array}$ & $\begin{array}{c}3694.50 \\
(150.75)^{* * *}\end{array}$ & $\begin{array}{c}2980.97 \\
(133.14)^{* * *}\end{array}$ & $\begin{array}{c}14167.17 \\
(519.82)^{* * *}\end{array}$ & $\begin{array}{c}3709.54 \\
(150.64)^{* * *}\end{array}$ & $\begin{array}{c}14235.86 \\
(519.60)^{* * *}\end{array}$ \\
\hline Work in a Metro Area (1=yes) & $\begin{array}{c}295.71 \\
(3.76)^{* * *} \\
3040.50 \\
(100.86)^{* * *}\end{array}$ & $\begin{array}{c}325.09 \\
(3.86)^{* * *} \\
3241.46 \\
(100.05)^{* * *}\end{array}$ & $\begin{array}{c}1171.57 \\
(14.81)^{* * *} \\
6616.88 \\
(401.57)^{* * *}\end{array}$ & $\begin{array}{c}294.96 \\
(3.77)^{* * *} \\
2984.29 \\
(100.74)^{* * *}\end{array}$ & $\begin{array}{c}1171.93 \\
(14.82)^{* * *} \\
6569.49 \\
(401.89)^{* * *}\end{array}$ \\
\hline $\begin{array}{l}\% \text { foreign born with }<\text { GED in } \\
\text { labor force, state-industry }\end{array}$ & $\begin{array}{c}-219.17 \\
(9.86)^{* * *} \\
0.0028\end{array}$ & $\begin{array}{c}-123.16 \\
(10.68)^{* * *} \\
0.0019\end{array}$ & $\begin{array}{c}-216.14 \\
(34.87)^{* * *} \\
0.0008\end{array}$ & $\begin{array}{c}-216.25 \\
(9.87)^{* * *} \\
0.0028\end{array}$ & $\begin{array}{c}-192.86 \\
(34.87) * * * \\
0.0008\end{array}$ \\
\hline Total Value of Shipments & $\begin{array}{l}(0.0002)^{* * *} \\
3.15\end{array}$ & $\begin{array}{l}(0.0001)^{* * *} \\
3.61\end{array}$ & $\begin{array}{l}(0.0002)^{* * *} \\
0.94\end{array}$ & $\begin{array}{l}(0.0002)^{* * *} \\
3.22\end{array}$ & $\begin{array}{c}(0.0002)^{* * *} \\
0.97\end{array}$ \\
\hline Capital/Labor Ratio & $\begin{array}{c}(1.25)^{* *} \\
0.0028\end{array}$ & $\begin{array}{c}(0.75)^{* * *} \\
0.0015\end{array}$ & $\begin{array}{c}(0.33)^{* * *} \\
0.0008\end{array}$ & $\begin{array}{c}(1.28)^{* *} \\
0.0027\end{array}$ & $\begin{array}{c}(0.33)^{* * *} \\
0.0008\end{array}$ \\
\hline Value of Export Shipments & $\begin{array}{l}(0.0008) * * * \\
-1264.26\end{array}$ & $\begin{array}{c}(0.0004)^{* * *} \\
-1321.54\end{array}$ & $\begin{array}{l}(0.0007) \\
-126.20\end{array}$ & $\begin{array}{c}(0.0008)^{* * *} \\
-1395.32\end{array}$ & $\begin{array}{l}(0.0007) \\
-129.79\end{array}$ \\
\hline Computer Share of Investments & $(286.43)^{* * *}$ & $(244.76)^{* * *}$ & (89.23) & $(292.29)^{* * *}$ & (89.53) \\
\hline $\begin{array}{l}\text { Import Competition (Complex), } \\
\text { WB 'Low' in } 1992\end{array}$ & $\begin{array}{c}5155.49 \\
(63.14)^{* * *} \\
9057.63 \\
(1,520.58)^{* *} \\
*\end{array}$ & $\begin{array}{c}3991.50 \\
(52.64)^{* * *} \\
-6744.67 \\
(1,844.88)^{* *} \\
*\end{array}$ & $\begin{array}{c}14509.85 \\
(151.09)^{* * *} \\
20726.19 \\
(4,361.07)^{* * *}\end{array}$ & $\begin{array}{c}5125.45 \\
(63.01)^{* * *} \\
29970.42 \\
(2,630.45)^{* * *}\end{array}$ & $\begin{array}{c}14510.75 \\
(151.13)^{* * *} \\
55400.47 \\
(8,443.96)^{* *} \\
*\end{array}$ \\
\hline Observations (rounded to 1000s) & 409000 & 396000 & 316000 & 409000 & 316000 \\
\hline R-squared & 0.29 & 0.25 & 0.18 & - & - \\
\hline $\mathrm{F}$ & 684.9 & 466.07 & 252.8 & 653.03 & 252.81 \\
\hline Prob $>$ F & 0 & 0 & 0 & 0 & 0 \\
\hline $\begin{array}{l}\text { Kleibergen-Paap rk LM statistic } \\
\text { (underidentification) }\end{array}$ & & & & 2618.625 & 6984.596 \\
\hline Chi-sq(1) P-val & & & & 0 & 0 \\
\hline $\begin{array}{l}\text { Cragg-Donald Wald F statistic } \\
\text { (weak identification) } \\
\text { Kleibergen-Paap rk Wald F } \\
\text { statistic } \\
\text { Instrument }\end{array}$ & & & & $\begin{array}{l}1.60 \mathrm{E}+004 \\
\text { EU Imports }\end{array}$ & $\begin{array}{l}2.60 \mathrm{E}+004 \\
\text { EU Imports }\end{array}$ \\
\hline
\end{tabular}

Robust standard errors in parentheses

* significant at $10 \%$; ** significant at $5 \%$; *** significant at $1 \%$

NB: Industry, State, and Year fixed effected included in all models 
Table 7: Task Intensities Interacted with Low Wage Import Competition

\begin{tabular}{|c|c|c|c|}
\hline & $(1)$ & $(2)$ & (3) \\
\hline & $\begin{array}{c}\text { All workers, } \\
\text { Dependent } \\
\text { Variable = Wages } \\
\text { OLS } \\
\end{array}$ & $\begin{array}{c}\text { All workers, } \\
\text { Dependent } \\
\text { Variable = Wages } \\
\text { OLS } \\
\end{array}$ & $\begin{array}{c}\text { All workers, } \\
\text { Dependent } \\
\text { Variable = Wages } \\
\text { OLS }\end{array}$ \\
\hline Sex, $1=$ male & $\begin{array}{c}19527.93 \\
(86.29)^{* * *} \\
-105.85\end{array}$ & $\begin{array}{c}12582.87 \\
(75.87)^{* * *} \\
1025.59\end{array}$ & $\begin{array}{c}16077.98 \\
(78.48)^{* * *} \\
-847.96\end{array}$ \\
\hline Nativity, $1=$ US born & $(162.99)$ & $(163.10)^{* * *}$ & $(163.35)^{* * *}$ \\
\hline $\begin{array}{l}\text { Ethnicity-Race Dummy (White \& Not } \\
\text { Hispanic=1) }\end{array}$ & $\begin{array}{c}7329.68 \\
(118.46)^{* * *}\end{array}$ & $\begin{array}{c}8315.72 \\
(118.16)^{* * *}\end{array}$ & $\begin{array}{c}7623.08 \\
(117.73)^{* * *}\end{array}$ \\
\hline Age & $\begin{array}{c}518.45 \\
(3.60)^{* * *} \\
4107.68\end{array}$ & $\begin{array}{c}518.91 \\
(3.58)^{* * *} \\
4788.51\end{array}$ & $\begin{array}{c}487.22 \\
(3.52)^{* * *} \\
4306.06\end{array}$ \\
\hline Work in a Metro Area (1=yes) & $(86.92)^{* * *}$ & $(87.27)^{* * *}$ & $(86.59)^{* * *}$ \\
\hline \multirow[t]{2}{*}{$\begin{array}{l}\% \text { foreign born with }<\text { GED in labor force, } \\
\text { state-industry }\end{array}$} & $\begin{array}{c}-315.50 \\
(9.10)^{* * *}\end{array}$ & $\begin{array}{c}-290.12 \\
(9.17)^{* * *}\end{array}$ & $\begin{array}{c}-334.60 \\
(9.09) * * *\end{array}$ \\
\hline & 0.00 & 0.00 & 0.00 \\
\hline Total Value of Shipments & $\begin{array}{c}(0.0001)^{* * *} \\
1.52\end{array}$ & $\begin{array}{c}(0.0001)^{* * *} \\
1.43\end{array}$ & $\begin{array}{c}(0.0001)^{* * *} \\
1.59\end{array}$ \\
\hline Capital/Labor Ratio & $\begin{array}{c}(0.19)^{* * *} \\
0.00\end{array}$ & $\begin{array}{c}(0.18)^{* * *} \\
0.00\end{array}$ & $\begin{array}{c}(0.19)^{* * *} \\
0.00\end{array}$ \\
\hline Value of Export Shipments & $\begin{array}{l}(0.0003) * * * \\
-511.33\end{array}$ & $\begin{array}{l}(0.0003)^{* * *} \\
-282.36\end{array}$ & $\begin{array}{l}(0.0003)^{* * *} \\
-414.50\end{array}$ \\
\hline Computer Share of Investments & $\begin{array}{c}(346.16) \\
347061.85\end{array}$ & $\begin{array}{c}(221.36) \\
-239953.33\end{array}$ & $\begin{array}{c}(282.69) \\
-181968.59\end{array}$ \\
\hline Import Competition (LWICOMP) & $\begin{array}{l}(9,463.40)^{* * *} \\
-10009.94\end{array}$ & $(9,870.82)^{* * *}$ & $(8,198.33)^{* * *}$ \\
\hline Routineness & $\begin{array}{l}(56.19) * * * \\
-34361.72\end{array}$ & & \\
\hline Routineness*LWICOMP & $(893.31)^{* * *}$ & & \\
\hline Analytical Complexity & & $\begin{array}{c}11869.00 \\
(71.42)^{* * *} \\
25142.41\end{array}$ & \\
\hline Complexity*LWICOMP & & $(1,040.53) * * *$ & \\
\hline Interpersonal Interaction & & & $\begin{array}{c}10332.21 \\
(61.16)^{* * *} \\
19361.77\end{array}$ \\
\hline Interpersonal*LWICOMP & & & $(886.32)^{* * *}$ \\
\hline Observations (rounded to 1000s) & $1,639,000$ & $1,639,000$ & $1,639,000$ \\
\hline R-squared & 0.24 & 0.24 & 0.25 \\
\hline
\end{tabular}

Robust standard errors in parentheses

* significant at 10\%; ** significant at 5\%; *** significant at $1 \%$

NB: Industry, State, and Year fixed effected included in all models 


\section{Appendix A}

Low-Wage Countries used in the Import Competition Measures

\begin{tabular}{lllll}
\hline Afghanistan & Comoros & Haiti & Maldives & Sao Tome \\
Bangladesh & Congo & Honduras & Mali & Sierra Leone \\
Bhutan & Eqypt & India & Mauritania & Solomon Isl. \\
Benin & Eq. Guinea & Indonesia & Mozambique & Somalia \\
Burkina Faso & Ethiopia & Kenya & Myanmar & Sri Lanka \\
Burundi & Gambia & Laos & Nepal & Sudan \\
Cambodia & Ghana & Lesotho & Niger & Tanzania \\
Ctr. African Rep. & Guinea & Liberia & Nigeria & Togo \\
Chad & Guinea-Bissau & Madagascar & Pakistan & Uganda \\
China & Guyana & Malawi & Rwanda & Vietnam \\
& & & & Zambia \\
\hline
\end{tabular}

NB: Classified according to the World Bank, using year 1992. 